Teologia i Moralność, volumen 14(2019), numer 1(25)

doi: 10.14746/tim.2019.25.1.14

ORCID: 0000-0002-1472-4005

WALDEMAR GRACZYK

Wyższe Seminarium Duchowne w Kaliszu

\title{
Na ratunek prawdziwej koncepcji przyjaźni, czyli Przyjaźń duchowa Elreda z Rievaulx jako remedium na kryzys przyjaźni wśród ludzi młodych
}

\section{Kryzys przyjaźni}

Przez wieki przyjaźń jawiła się człowiekowi jako najwyższy wyraz miłości. W filozofii starożytnej Grecji oraz kulturze rzymskiej stanowiła jeden z głównych tematów przewodnich ${ }^{1}$, które miały praktyczne odzwierciedlenie, albowiem człowiek kultury klasycznej nie wyobrażał sobie życia bez doświadczenia przyjaźni i bez przyjaciół. Nie będzie zatem przesadą stwierdzenie, że w świecie antycznym człowiek samotny, żyjący bez kręgu bliskich mu przyjaciół, uchodził za duchowo umarłego. Myśl biblijna, a następnie teologia patrystyczna i średniowieczna, wraz z Augustynem, Elredem z Rievaulx czy Tomaszem z Akwinu, rozpoczęła proces chrystianizacji koncepcji przyjaźni. Jej pozycji w ludzkim doświadczeniu nie zburzyła doktryna oświeceniowa czy pozytywistyczna i choć sama przyjaźń nie podlegała już tak wnikliwej analizie jak wcześniej, to pozostała jednak jednym z najbardziej istotnych doświadczeń człowieka. Również w epoce modernizmu, epoce postmodernistycznej czy postchrześcijańskiej pozornie nic się nie zmieniło, ponieważ nadal przyjaźń jest postrzegana jako rzeczywistość wpisana w naturę człowieka, która kształtuje jego byt prawie tak samo, jak doświadczenie miłości oblubieńczej.

\footnotetext{
${ }^{1}$ Wystarczy wspomnieć w tym miejscu Platona z jego dialogiem o przyjaźni Lizys; Arystotelesa, autora Etyki Nikomachejskiej, w której zajmuje się zagadnieniem przyjaźni w księgach: VIII i IX; Cycerona z jego słynnym traktatem o przyjaźni Leliusz czy Senekę, którego Listy moralne do Lucyliusza zawierają wiele treści dotyczących omawianego zagadnienia.
} 
Pomimo istotnej roli fenomenu przyjaźni w naszej kulturze można dziś zauważyć pewne symptomy pojawiającego się kryzysu, nie tyle samej przyjaźni, ile jej właściwego rozumienia, przeżywania i kształtowania. W epoce social network człowiek sądzi, że ma ogromną liczbę przyjaciół, którzy jednak są nimi jedynie w rzeczywistości wirtualnej. Niezależnie od ogromu środków komunikacji, jakimi dziś dysponujemy, można zaobserwować wzrost poczucia samotności, szczególnie wśród ludzi młodych. Wielu z nich nie ma się do kogo zwrócić o radę czy pomoc, mimo że mają tysiące znajomych czy „przyjaciół” w mediach społecznościowych. Okazuje się, że proces globalizacji wcale nie musi prowadzić do pogłębienia tak ważnej relacji w życiu człowieka, jaką jest przyjaźń. Ponadto wszechobecny pośpiech, życie wypełnione pracą i innymi obowiązkami nie pozwala często pogłębić naszych płytkich relacji, które zatrzymują się przeważnie na etapie koleżeństwa, ale nie mają wiele wspólnego z prawdziwą koncepcją przyjaźni, jaką tworzyli myśliciele greccy, rzymscy i chrześcijańscy (por. Graczyk 2017, s. 17).

Przyjaźń, podobnie jak każda inna głębsza relacja, wymaga odpowiedzialności, przede wszystkim dlatego, że wyraża to, kim jest człowiek, ukazuje jego wnętrze oraz wychowuje to, co można określić jako istotę człowieczeństwa, a więc, mówiąc jaśniej, przyjaźń służy procesowi dojrzewania i dorastania, czyli edukuje człowieka². Nie można zatem traktować jej jako zwykłego koleżeństwa, relacji zbudowanej jedynie na sentymentach, bliżej nieokreślonych uczuciach albo szukaniu korzyści. Współczesny świat zatraca lub banalizuje podstawowe pojęcia, konstytuujące byt człowieka i całej ludzkości, takie jak: dobro, prawda, piękno, miłość i przyjaźń. Dziś liczy się to, co opłacalne, łatwe, szybkie i przyjemne. Dlatego możemy z całkowitą pewnością stwierdzić, że obecnie świat preferuje model przyjaźni utylitarystycznej, która trwa do momentu, kiedy kończy się osobista korzyść jednej ze stron ${ }^{3}$. Francesco Alberoni twierdzi nawet, że wrogiem przyjaźni są zbudowane na filozofii utylitarystycznej wielkie struktury społeczne, np. wolny rynek (por. Alberoni $2006^{3}$, s. 132). Ludzie młodzi, którzy są przecież dziećmi swoich czasów, przeżywają więc ,przyjaźnie”, nie rozumiejąc do końca ich istoty oraz tego, co one powinny nieść ze sobą i do czego winny prowadzić. Należy więc niestety ocenić

\footnotetext{
${ }^{2}$ Por. O'Neil 1996, s. 99: "Psychological theories of human development depict growth as a progressive movement from self-absorption as an infant to the mature adult who has a clear selfidentity and freely comits himself or herself to relationships with others. These include more personal relationships such as friendship and marriage, as well as an awareness of oneself as a member of the human community"; Seidl 1995, s. 405.

${ }^{3}$ Por. Lodovici 2009, s. 16: "Le etiche moderne non riescono a preservare atti di gratuità come l'amore e l'amicizia, perché non permettono di esercitare questi atti come espressione ed incarnazione della sollecitudine verso gli altri, verso il bene degli altri in quanto altri, bensì ingiungono al soggetto di considerare l'altro come tramite attraverso cui si soddisfa un obbligo o si producono le migliori conseguenze possibili”.
} 
czasy nam współczesne jako epokę kryzysu przyjaźni ${ }^{4}$, również tej przeżywanej przez młodych ludzi. Chyba jak nigdy dotąd aktualne okazuje się pytanie: Czy dzisiejsza młodzież potrafi się zaprzyjaźnić?

\section{Przyjaźń w życiu młodego człowieka}

Nie ma wątpliwości, że młody człowiek nawiązuje relacje ze swoimi rówieśnikami $\mathrm{w}$ różnych celach. Więzi te $\mathrm{z}$ pewnością pod względem jakościowym również są bardzo zróżnicowane. Nie ma chyba jednak młodego człowieka, poza wypadkami osób chorych psychicznie, który nie chciałby nawiązać relacji z drugim człowiekiem, mimo że może mieć problemy z realizacją takiego pragnienia. Wśród różnych potrzeb człowieka znajduje się przecież pragnienie życia w społeczności, a więc nawiązania i podtrzymywania więzi z innymi. Ta potrzeba jest wręcz wpisana $\mathrm{w}$ naturę człowieka, jest jednym z jej fundamentów, tak samo jak zaspokojenie głodu czy przeżywanie swojej płciowości. W dzisiejszym społeczeństwie, w którym żyje coraz więcej osób młodych bez rodzeństwa, istnieje, pomimo wskazanego wyżej kryzysu, pragnienie budowania trwałych relacji, wśród których przyjaźń należy do najważniejszych. Młodzi ludzie czują taką potrzebę, mimo że nie zawsze dobrze rozumieją, czym jest i czym może być przyjaźń. W epoce kryzysu małżeństwa i rodziny, spadku liczby urodzeń, w dobie singli, wzrastającej liczby rozwodów i separacji, ryzyko doświadczenia samotności jawi się jako jeden z palących problemów młodego człowieka. Obecność przyjaciela może więc stać się pewnego rodzaju „deską ratunkową" dla tych, którzy panicznie obawiają się samotności, a przecież lęka się jej praktycznie każdy reprezentant młodej generacji (por. Capodieci 2012, s. 88-91).

\section{Uratować przyjaźń}

Pragnienie przyjaźni jest więc obecne w młodym człowieku, ale należy, tym bardziej w epoce kryzysu międzyludzkich więzi, jeszcze precyzyjniej określić, czym jest przyjaźń i jaka winna być jakość relacji określanych tym

\footnotetext{
${ }^{4}$ Por. Seidl 1995, s. 405: "Chi si occupa dell'amicizia oggi non può fare a meno di accorgersi che essa si trova in crisi, se la paragona con l'idea e la realtà dell'amicizia nei tempi passati [...] Certamente l'amicizia non è stata mai facile, ma evidentemente oggi si aggiungono condizioni aggravanti che fanno apparire la vera amicizia più incerta, problematica, persino più illusoria di una volta”. H. Majkrzak również wskazuje na faktory, które doprowadziły do kryzysu przyjaźni w ujęciu klasycznym i chrześcijańskim we współczesnym świecie: brak czasu na budowanie trwałych relacji, ucieczka w świat iluzji, kult władzy, próżność, poszukiwanie pochwały, indywidualizm, scjentyzm (por. Majkrzak 2006, s. 130).
} 
mianem. Innymi słowy, należałoby odnaleźć paradygmat, który byłby jasnym drogowskazem, w jaki sposób budować ten rodzaj relacji, aby była trwała i przynosiła dojrzały owoc. Uważam, że pewną propozycją, oczywiście nie jedyną, może być przyjaźń duchowa, którą proponuje w traktacie De spirituali amicitia $^{5}$, wzorowanym na słynnym dziele Cycerona Leliusz o przyjaźni (Cicerone 1985), Elred z Rievaulx ${ }^{6}$, XII-wieczny opat cysterski, nazywany „Bernardem północy". Oczywiście można zadać sobie pytanie, czy traktat o przyjaźni z XII wieku może być aktualny dla współczesnej młodzieży. Wydaje się pewnym nonsensem korzystanie z dzieła autora, który żył ponad 800 lat temu, a na dodatek był duchownym mieszkającym w klasztorze. Jednak już pierwsza analiza jego opracowania ukazuje nam, oczywiście po uprzednim przełożeniu jego przemyśleń na bardziej współczesny język, że będzie możliwe uzyskanie odpowiedzi na pytanie, czym jest przyjaźń, jaka jest jej natura i w jaki sposób być przyjacielem dzisiaj. Przyjaźn duchowa Elreda z Rievaulx może być jedną z kilku propozycji odnowienia koncepcji interesującej nas relacji i ukazania jej bogactwa ludziom młodym, pragnącym budować trwałe związki, które będą oparte na wartościach płynących z Ewangelii.

Traktat Elreda jest niezwykle wartościowy nie tylko dlatego, że jest wynikiem jego pracy naukowej, ale również dlatego, że świadczy o jego osobistym doświadczeniu budowania przyjaźni $\mathrm{w}$ różnych okresach życia. $Z$ pewnością dzieło „doktora przyjaźni” było wzorowane nie tylko na Laelius de amicitia, ale również na dziełach Augustyna czy Hieronima. Dzięki tak szerokiemu

\footnotetext{
${ }^{5} \mathrm{~W}$ niniejszym opracowaniu będę korzystał z polskiego tłumaczenia M. Wylęgały: Elred z Rievaulx, Przyjaźń duchowa, Kielce 2010, oraz oryginału łacińskiego: Aelredus Rievallensis, De spirituali amicitia, Migne PL 195, 659-702.

${ }^{6}$ Elred z Rievaulx (ok. 1110-1167) - jego imię występuje w różnych wariantach: łac. Aelredus, Aelretus, Elredus, Elretus, niem. Edelret, Elret, Elred, ang. Aelret, Elret, Ethelred, i oznacza 'męża szlachetnego w radzie'. Elred urodził się w Hexham, na pograniczu Anglii i Szkocji (Northumbria). Pochodził z rodziny kapłańskiej (w jego czasach obowiązkowy celibat nie był jeszcze aż tak rozpowszechniony). Wykształcenie zdobył w szkole benedyktyńskiej w Durham oraz na dworze króla szkockiego Dawida I (ok. 1082-1153, król od 1124), gdzie robił zawrotną karierę (miał nawet zostać prymasem Szkocji), nagle przerwaną przez jego wybór życia w opactwie cysterskim w Rievaulx (1134). W 1142 r. został mianowany mistrzem nowicjatu w Rievaulx, a rok później opatem w Revesby (Lincolnshire). W roku 1147 wybrano go na opata Rievaulx, gdzie pozostał aż do swojej śmierci. Poświęcał się pracy duszpasterskiej, zarządzał rozległym klasztorem, wizytował opactwa filialne, pozostając ważną osobistością w Kościele i w życiu polityczno-społecznym Szkocji i Anglii. Nie zaniedbywał swojej działalności pisarskiej - oprócz swojego głównego dzieła o przyjaźni jest autorem takich dzieł, jak: Genealogia regum Anglorum, De Iesu puero duodenni, De sanctis Ecclesiae Hagulstadensis, Sermones de oneribus, De institutione inclusarum, Vita s. Eduardii, regis et confessoris, Speculum caritatis. Elred zmarł 12 stycznia 1167 r. po długiej chorobie i został pochowany w kapitularzu klasztornym. Najprawdopodobniej nie został kanonizowany oficjalnie, ale jego kult musiał być dość żywy, skoro Kapituła Generalna cystersów z 1467 r. uznała, że opactwo w Rievaulx może celebrować jego święto. W kalendarzu liturgicznym wspomina się św. Elreda 12 stycznia (por. Wylęgała 2010, s. 12-18; Pezzini 2004, s. 8-21).
} 
kontekstowi powstawania Przyjaźni duchowej można uznać, że - jak wskazuje Marcin Rutecki - Elred jest ,pierwszym filozofem, który w sposób systematyczny wyłożył doktrynę przyjaźni w jej chrześcijańskiej odmianie" (Rutecki 2017, s. 59). Opracowanie naszego autora jest więc wypadkową ludzkiego doświadczenia oraz rzetelnej pracy naukowej, połączonej ze zmysłem wiary, a także ze światłem Bożego objawienia. Sam Elred przyznaje, że odczuwał pragnienie stworzenia dzieła, które będzie mogło być podstawą do tworzenia zdrowych relacji przyjaźni, opartych na solidnych fundamentach (por. Elred z Rievaulx 2010, Prolog, s. 6-9).

Autor podzielił swoje opracowanie na trzy części, poprzedzone bardzo osobistym prologiem. Każda $\mathrm{z}$ nich przybiera formę dialogu, który toczy się wśród mnichów, zainteresowanych pogłębieniem swoich przyjaźni. Pierwszy dialog rozgrywa się pomiędzy Elredem a Iwonem (1160) w jednym z klasztorów podlegających pod opactwo w Rievaulx. Kolejne dialogi pomiędzy Elredem, Walterem i Gracjanem (księgi: druga i trzecia) mają miejsce w samym opactwie i odbywają się kilka lat później (1164-1167; por. Wylęgała 2010, s. 19). Pierwsza księga zawiera dyskurs, który prowadzi rozmówców do stworzenia definicji przyjaźni, powstałej na wzór definicji Cycerona z jego dzieła ${ }^{7}$. Ponadto Elred rozgranicza różne rodzaje tej relacji, wskazując na przyjaźń duchową jako formę przyjaźni we właściwym znaczeniu tego terminu, oraz snuje refleksje nad genezą i naturą omawianego zjawiska. Księga druga opisuje korzyści, które płyną z przyjaźni, oraz zawiera opis trzech „pocałunków” (cielesnego, duchowego, mistycznego), które w niej istnieją. Uczestnicy dialogu zastanawiają się również, jakie są granice tej relacji. Ostatnia księga wskazuje etapy rozwijania się omawianej więzi: wybór przyjaciela, poddanie go próbie, przyjęcie go i troskę o niego (por. Wylęgała 2010, s. 19-20). Analizując wybrane fragmenty Przyjaźni duchowej, spróbujmy zatem zobaczyć, co Elred może przekazać młodemu człowiekowi na ten temat.

\section{Problemy młodzieńczych przyjaźni}

Nie jest łatwo znaleźć przyjaciela, ale też nie jest łatwo nim być. Rzecz w tym, że dojrzewanie do takiej roli i bycie wiernym temu swego rodzaju powołaniu to trudna sztuka. Przyjaźń nie jest jedynie zbiorem pięknych chwil widocznych na zdjęciach czy filmach, ale często jest wypełniona również cierpieniem. Tak jak inne relacje, przechodzi przez kryzysy i burze, które nie oznaczają jej końca, ale mogą stać się punktem zwrotnym we wzajemnych re-

\footnotetext{
${ }^{7}$ Por. Aelredus Rievallensis, De spirituali amicitia, I, 11: "Nonne satis tibi est hinc quod ait Tullius: amicitia est rerum humanarum et divinarum cum benevolentia et caritate consensio?"
} 
lacjach. Elred z Rievaulx był świadomy, że budowanie przyjaźni nie jest procesem łatwym - wręcz przeciwnie - zakłada pewien trud i wymaga wiele czasu. Nie inaczej jest w przypadku ludzi młodych. Jednak dzisiaj wydaje się to jeszcze trudniejsze, ponieważ młodzież epoki fast-food przyzwyczaiła się do tego, że wszystko musi się dziać szybko, sprawnie i bezproblemowo. Jednak szybkie i nagłe zaangażowanie niekontrolowanych emocji i uczuć, bez poddania danej relacji rozumowi czy tzw. zdrowemu rozsądkowi, może przyczynić się do jej destrukcji, nawet zanim jeszcze dana relacja mogłaby być określona jako przyjaźń. Mistrz z Rievaulx z własnego doświadczenia wiedział, że to, co nazywa się przyjaźnią, może być płytkie, jeśli fundamentem są jedynie uczucia:

W czasach, gdy jeszcze jako chłopiec pobierałem nauki i z wielkim upodobaniem przyjmowałem życzliwość swych towarzyszy, pośród błędnych obyczajów, na jakie zwykle narażony bywa ten wiek, poddałem się całkowicie władzy uczuć i tak dalece poświęciłem się miłości, iż nic nie wydawało mi się przynosić większej słodyczy, przyjemności i pożytku niż być kochanym i kochać" (Elred z Rievaulx 2010, Prolog, 1; por. Czubak 2004, s. 70).

Przyjaźń wieku młodzieńczego może się więc charakteryzować przede wszystkim pragnieniem przyjemności oraz zbytnim zaangażowaniem emocji, co czasem przeradza się $\mathrm{w}$ chęć posiadania drugiego człowieka na wyłączną własność czy nawet zazdrość, bardziej charakterystyczną dla stanu zakochania niż przyjaźni ${ }^{8}$. Opat z Rievaulx charakteryzuje młodzieńczą przyjaźń dość kategorycznie i zaznacza, że takiego sposobu przeżywania relacji należy unikać:

Istnieje przyjaźń młodzieńcza, którą rodzi zmienne i lubieżne uczucie. Narzuca się każdemu, kto obok niej przechodzi. Jest bezmyślna, nieodpowiedzialna, nieumiarkowana, bezwzględna wobec czyjejś korzyści lub szkody. Takiej przyjaźni przez krótki czas towarzyszą gwałtowne uczucia, bardzo silna więź, nęcące propozycje. Lecz uczucie pozbawione rozumu jest zwierzęcym odruchem, skłonnym do wszystkiego, co zakazane, co więcej - nie potrafi dostrzec różnicy pomiędzy tym, co jest dozwolone, a tym, co nim nie jest. Chociaż uczucie często wyprzedza przyjaźń, nigdy jednak nie należy mu ulegać, jeśli nie kieruje nim rozum, nie powściąga cnota, nie rządzi sprawiedliwość (Elred z Rievaulx 2010, II, 57).

Łatwo można wywnioskować, że młodzieńcza przyjaźń, według Elreda, potrzebuje ascezy, aby była trwała. W przeciwnym razie może się szybko zakończyć, tym bardziej jeżeli nie będzie poddana autorefleksji, która pozwoli-

\footnotetext{
${ }^{8}$ Por. Alberoni 2006, s. 92: "A volte gli adolescenti hanno, nei riguardi dei loro amici, atteggiamenti che noi consideriamo tipici degli innamorati: 1'attaccamento esclusivo, la gelosia"; Pezzini 2004, s. 38.
} 
łaby przekształcić przyjaźń młodzieńczą w dojrzałą relację dwóch równych sobie podmiotów, które nawzajem obdarowują się, a nie tylko biorą albo jedynie dają. Młodzi ludzie mają się więc nauczyć przyjaźni, poddać ją pod osąd rozumu, tworzyć ją z czystymi intencjami, z właściwą roztropnością i umiarkowaniem (por. Dotto 1995, s. 552). Jeżeli relacje, które młodzież nazywała przyjaźnią, kończą się dość szybko, to trudno nazwać je właściwą przyjaźnią (por. Elred z Rievaulx 2010, I, 24).

W tym kontekście warto zwrócić uwagę na rodzaje przyjaźni według Elreda z Rievaulx. Wyróżnia on następujące jej typy: cielesną, światową i duchową. Pierwsza charakteryzuje się brakiem jakiejkolwiek pracy nad sobą i szukaniem przyjemności. Druga zaś związana jest z zyskiem, a nawet można by powiedzieć pewnym wspominanym już utylitaryzmem. Natomiast trzecia, prawdziwa przyjaźń, opiera się na duchowym podobieństwie i postępowaniu w dobru (por. Elred z Rievaulx 2010, I, 38). Dwie pierwsze Elred uważa za fałszywe przyjaźnie, jedynie duchowa zasługuje na miano prawdziwej. Przyjaźń cielesna nie tylko jest fałszywa, ale prowadzi również do grzechów. Magdalena Czubak, komentując poglądy Mistrza z Rievaulx, wskazuje, że w takiej niezdrowej relacji liczy się przede wszystkim chęć posiadania drugiej osoby i jej ciągłego towarzystwa, co prowadzi do zniewolenia, a nawet uzależnienia się od bliźniego. Młodzież z pewnością szczególnie narażona jest na więzi, których natura zakłada dbanie bardziej o siebie, własną przyjemność niż o dobro drugiej osoby (por. Elred z Rievaulx 2010, I, 39-41; Czubak 2004, s. 75-76; Rutecki 2017, s. 80-82). Tymczasem przyjaźń, która ma być relacją dwóch równych sobie podmiotów, musi być związkiem wypełnionym wolnością i szacunkiem wobec drugiej osoby. Bardzo prawdopodobne jest, że dzisiejsza młodzież, i nie tylko ona zresztą, może błędnie rozumieć relację przyjacielską, ale $-z$ drugiej strony - silne poczucie niezależności i pragnienie wolności mogą przyczynić się do tego, że młodzi sami odkryją, iż w przyjaźni mają się czuć wolni, a nie zniewoleni przez drugą osobę. Intuicja Elreda, demaskująca fałszywą przyjaźń, bierze więc pod uwagę, że człowiek roztropny, inteligentny, pragnący trwałych związków, dość szybko uświadomi sobie, iż nie może żyć w przyjaźni posesywnej, ,cielesnej”, która nastawiona jest bardziej na otrzymywanie niż na dawanie.

Podobnie ma się rzecz z przyjaźnią światową, czyli doczesną. Celem takiej relacji jest jakaś wymierna korzyść, a więc taki związek trwa tak długo, jak długo można osiągać dzięki niemu pewien pożytek. Pomimo że zakłada ona zdaniem Elreda - zgodę w sprawach ludzkich, to jednak trudno określić ją mianem prawdziwej przyjaźni, gdyż jest egoizmem nazwanym jedynie przyjaźnią (por. Elred z Rievaulx 2010, I, 42-44; Czubak 2004, s. 76-77). Żądza dóbr materialnych nie może być celem takiej relacji, ponieważ prawdziwa przyjaźń zakłada bezinteresowność. W dzisiejszym świecie konsumpcji młodzież jest 
szczególnie narażona na doświadczenie takiej płytkiej relacji, która bardziej zwraca uwagę na zasobność portfela niż wartość drugiej osoby. Podążając za tą myślą, nie sposób nie zauważyć, że przyjaźń światowa nie musi dotyczyć jedynie korzyści materialnych. Dziś jesteśmy narażeni na budowanie relacji, w których liczy się wyłącznie nasza korzyść - jakakolwiek, a więc duchowa, emocjonalna, psychiczna. Jeśli dla kogoś prawdziwym celem jest osiągnięcie tego typu komfortu, to przyjaciel przyjaciela $\mathrm{z}$ dnia na dzień może stać się niepotrzebny. Młodzieńczym przyjaźniom grozi więc rozpad wraz z ustaniem pewnej atrakcyjności duchowo-emocjonalnej przyjaciela, czasami fizycznej, obecnej szczególnie na początku relacji. Innymi słowy, osobie pozostającej na tym etapie rozwoju grozi przedmiotowe traktowanie człowieka, który może stać się „narzędziem” lub „zabawką" dla osiągnięcia pewnego komfortu psychicznego.

Jaką więc relację Mistrz z Rievaulx uważa za prawdziwą przyjaźń? Nazywa ją przyjaźnią duchową i wyjaśnia, że ,pragniemy [jej] nie ze względu na korzyść doczesną, jakiej ktoś może nam udzielić, ani z jakiejkolwiek przyczyny zewnętrznej, lecz dla jej własnej, naturalnej godności i z potrzeby ludzkiego serca, tak że korzyścią z niej płynącą i nagrodą za nią nie jest nic innego, tylko ona sama" (Elred z Rievaulx 2010, I, 45). Taka przyjaźń może zaistnieć pomiędzy tymi, którzy pragną wznosić gmach swojego życia na dobru, a więc mają podobny cel w swoim życiu - zgodność w człowieczeństwie, ale również $\mathrm{w}$ dążeniu ku wartościom duchowym, których wyrazicielem będzie wiara w najwyższy Byt, uważany za kwintesencję Dobra jako takiego. Takie pragnienie połączone jest z miłością oraz życzliwością względem drugiej osoby ${ }^{9}$. W przyjaźni duchowej najlepiej uwidacznia się więc to, że jest ona formą miłości, w której kocha się przyjaciela ze względu na samo jego istnienie. Przeżywanie przyjaźni w duchu wzajemnego szacunku i miłości, pragnienia dobra dla drugiego, jest najlepszym lekarstwem na konsumpcyjne spojrzenie na tę wyjątkową dla młodego człowieka relację. Nie oznacza to jednak, że przyjaźń nie niesie ze sobą wielu radości. Wręcz przeciwnie, w przyjaźni młody człowiek winien doświadczyć, że jest ona darem płynącym od drugiej osoby, a więc jest niczym niezasłużona, jest darmowa, a na taki dar należy również właściwie odpowiedzieć, co niesie ze sobą także konkretne korzyści.

Elred, przytaczając przykłady biblijnych przyjaźni, np. Dawida i Jonatana (por. Elred z Rievaulx 2010, II, 62-63), wskazuje, że wszelkie korzyści płynące $\mathrm{z}$ tego typu więzi są jej wynikiem, a nie celem, bo one nie poprzedzają omawianej relacji, lecz wynikają z niej: ,Jeśli bowiem wierna przyjaźń, która

\footnotetext{
${ }^{9}$ Por. Aelredus Rievallensis, De spirituali amicitia, I, 46: "Amicitia itaque spiritalis inter bonos, vitae, morum, studiorum que similitudine parturitur, quae est in rebus humanis atque divinis cum benevolentia et caritate consensio".
} 
istnieje pomiędzy ludźmi prawymi, rodzi liczne i wielkie korzyści, to jednak bez najmniejszej wątpliwości nie wynika ona z korzyści, lecz korzyści pochodzą z przyjaźni”" (Elred z Rievaulx 2010, II, 62). Młodzież, aby właściwie żyć w przyjaźni, powinna więc przewartościować swoje relacje, pytając się o ich cel. Jeżeli punktem docelowym jestem ja sam, to nie będę potrafił właściwie budować przyjaźni. Jeżeli natomiast ją samą umieszczę jako priorytet, zwrócę uwagę na drugą osobę, to będę miał szansę przekroczyć siebie oraz własny egoizm.

W budowaniu przyjaźni należy więc określić na początku właściwy jej cel. Jeżeli ideą będzie tworzenie relacji, w której urzeczywistnia się bycie bezinteresownym darem dla drugiej osoby, to taka więź ma rację bytu i może dawać tym, którzy w niej trwają, wymierne dobra. Opat z Rievaulx wymienia kilka takich dóbr, które płyną z duchowej przyjaźni. Są to: wzajemna troska, modlitwa wstawiennicza za przyjaciela, dzielenie stanów radości i smutku, wzajemne wsparcie i pomoc, dodawanie odwagi, pocieszenie, cierpliwe znoszenie drugiej osoby, wzajemny szacunek i upominanie (por. Elred z Rievaulx 2010, III, 102-103). Podążając za myślą Elreda, można powiedzieć, że problemem młodzieńczych przyjaźni nie jest tylko dzisiejszy kryzys tej relacji czy w ogóle stosunków interpersonalnych, ale określenie ich celu, a więc odpowiedź na pytanie, czego i kogo tak naprawdę szukam w danej przyjaźni. Koncepcja przyjaźni duchowej cysterskiego opata może więc być skutecznym remedium dla przyjaźni wśród dzisiejszej młodzieży. Warto więc uwypuklić konkretne korzyści, oprócz tych, które już wskazano, płynące z tej wizji relacji, aby zachęcić młodego człowieka do jej właściwego kształtowania.

\section{Terapia przyjaźni}

Według Elreda przyjaźń odgrywa rolę w całym planie zbawienia i w poszczególnych jego częściach, począwszy od dzieła stworzenia, przez upadek pierwszych rodziców, aż do odkupienia, które przyniósł Jezus Chrystus. Jego teologia przyjaźni jest bardzo rozbudowana, ponieważ sięga samego początku dziejów świata i człowieka. Mistrz z Rievaulx wskazuje, że przyjaźń przynależy do natury człowieka i jest fundamentem ludzkich relacji (por. Billy 2002, s. 69-70): „Przeto przyjaźń, podobnie jak miłość, istniała najpierw pomiędzy wszystkimi ludźmi i przez wszystkich była praktykowana, a przetrwała wśród nielicznych na mocy prawa naturalnego" (Elred z Rievaulx 2010, I, 59). Grzech pierworodny naruszył harmonię międzyludzkich relacji i przyjaźni z Bogiem, ale całkowicie jej nie zburzył, a przyjaźń odegrała znaczącą rolę w odkupieniu człowieka. Śmierć i zmartwychwstanie Chrystusa przywróciły ludziom zdolność do przyjaźni z Bogiem i z drugim człowiekiem, ponie- 
waż Stwórca nigdy do końca nie zerwał z nimi więzów przyjaźni. Dzięki tej niezerwanej nigdy do końca relacji z Bogiem człowiek zostaje uzdrowiony z niemocy bycia i stawania się przyjacielem, a zatem przyjaźń Boża ma uzdrawiający charakter ${ }^{10}$. Domenico Pezzini, analizując tok myślenia cysterskiego opata, stwierdza nawet, że przyjaźn jest sposobem na powrót do stanu przed grzechem pierworodnym albo pewnym preludium przed powrotem do niego, ponieważ ma aspekt terapeutyczny, dzięki któremu uzdrawia człowieka ze zła grzechu $^{11}$.

Przenosząc tę myśl Elreda na grunt omawianego problemu przyjaźni ludzi młodych, można uznać, że ma ona dla nich wymiar terapeutyczny. Mistrz z Rievaulx stwierdza jednoznacznie:

Przyjaciel, mówi Mędrzec, jest lekarstwem życia. Jakież to niezwykłe! Nie ma bowiem silniejszego lub skuteczniejszego czy doskonalszego lekarstwa na nasze rany, jakich doznajemy w różnych okolicznościach życiowych, niż mieć kogoś, kto śpieszyłby ze współczuciem we wszelkim nieszczęściu, a w chwilach szczęścia cieszył się naszą radością. Wtedy to dwaj przyjaciele, jak mówi Apostoł, ramię w ramię wspólnie niosą swoje ciężary, co więcej, każdy z nich łatwiej znosi krzywdę własną niż przyjaciela. Przyjaźń więc dodaje blasku pomyślności, a przeciwności, dzielą je i biorąc ich część na własne barki, tagodzi. Przeto najlepszym lekarstwem życia jest przyjaciel (Elred z Rievaulx 2010, II, 12-13).

Wobec tego przyjaźń może przyczynić się do wewnętrznego uzdrowienia różnych obszarów życia młodego człowieka i być nieodzownym wsparciem w trudnych chwilach. Psychoterapeuci stwierdzają, że osoba dojrzała to ta, która potrafi budować bliskie, głębokie i odpowiedzialne relacje, takie jak przyjaźń. W przeciwnym razie celem każdej terapii jest doprowadzenie człowieka do stanu, w którym będzie mógł nawiązywać wspomniane więzi (por. Grzywocz 2014, Konferencja 2).

Przyjaźń jest więc dla młodego człowieka środkiem realizowania swoich potrzeb, wynikających z jego natury, a więc potrzeby socjalizacji, bycia w dialogu, realizacji samego siebie poprzez spotkanie z drugim. Prowadzi ona do odkrycia, że nie mogę być sam na tym świecie, ponieważ będąc sa-

${ }^{10}$ Por. Billy 2002, s. 72-73: "His theology of friendship is eminently positive, one that flows from the love of God who, through the death of Christ, enables a person once again to enjoy the friendship of God [...] Friendship, for Aelred, is the medicine of life, because it ultimately brings a person into relationship with Christ, who is the Way, the Truth, and the Life (Jn 14:6). It plays a healing, even elevating role in the human sojourn". Por. także: Elred z Rievaulx 2010, III, 74.

${ }^{11}$ Por. Pezzini 2004, s. 50: "Aelredo veda nell'amicizia una sorta di ritorno all'Eden, o, se si vuole mettere la cosa in prospettiva, un preludio del paradiso: essa infatti ha, nei confronti del male, un aspetto terapeutico, in quanto ci protegge e ci conforta dalla cattiveria che si vede e da quella che si soffre; ce ne ripara, in qualche modo"; Elred z Rievaulx 2010, I, 59. 
motnym, będę jednocześnie niespełniony i nieszczęśliwy. Wobec tego jedną z najlepszych ,terapii” dla młodego człowieka może być prawdziwa przyjaźń duchowa, którą proponuje Elred z Rievaulx. Rany, które noszą młodzi ludzie w sobie, często głęboko ukryte i niewyjawione przed nikim, mogą zostać uzdrowione poprzez trwanie w przyjaźni. Co więcej, właśnie z niej młodzi mogą czerpać siłę do zmierzenia się z życiowymi problemami oraz wyborami, które czekają na nich u progu dorosłości.

\section{Przyjaźń duchowa a ewangelizacja młodzieży}

Jak pokazuje doświadczenie prawie każdego człowieka pragnącego realizować powołanie do przyjaźni, ludzkie relacje naznaczone są również kruchością i słabością, a więc potrzebują wciąż odnowy i świeżego ducha. W tym kontekście młody człowiek, widząc nieudane próby tworzenia relacji, może dostrzec, że jego przyjaźnie potrzebują oparcia, pewnego zakotwiczenia w rzeczywistości przerastającej jego samego i jego możliwości, a więc potrzebują umiejscowienia $\mathrm{w}$ transcendencji. $\mathrm{W}$ ten sposób pojawia się kwestia przyjaźni z Bogiem i jej właściwego rozumienia, a - co za tym idzie - możliwość ewangelizacji dzisiejszej młodzieży poprzez doświadczenie przyjaźni. Dla wielu teologów przyjaźń nie jest kategorią teologiczną, ale, z drugiej strony, wielu mówi też o istnieniu pewnej teologii przyjaźni (por. Mendonça 2013). Z pewnością można uznać Elreda z Rievaulx za prekursora tak pojmowanej teologii. Odważył się on nawet na parafrazę słów zaczerpniętych z $1 \mathrm{~J} 4,16$. Na pytanie Iwona: „Czy mógłbym powiedzieć o przyjaźni to, co Jan, przyjaciel Jezusa, mówi na temat miłości: Bóg jest przyjaźnią?”"12 - Mistrz odpowiada: „Z pewnością wyrażenie to jest niezwykłe i nie znajdziesz go w Piśmie świętym. Jednak nie waham się przypisać przyjaźni tego, co niżej zostało powiedziane o miłości: K to trwa w przyjaźni, trwa w Bogu, a Bóg trwa w nim"13. Elred nie wyłącza więc możliwości mówienia o Bogu i relacji człowieka z Nim w kategoriach przyjaźni, a nawet preferuje taki styl uprawiania teologii.

Dla młodzieży, której relacje z rodzicami czy rodziną bywają często problematyczne, przyjaźń może stanowić płaszczyznę odniesienia dla tworzenia więzi opartych na poświęceniu, szacunku, szukaniu dobra dla drugiego, a także punkt wyjścia do rozpoczęcia relacji z Bogiem. Podstawowym obrazem Boga w Piśmie Świętym jest oczywiście Ojciec, ale dzisiejsza młodzież,

\footnotetext{
${ }^{12}$ Elred z Rievaulx 2010, I, 69: „Dicam ne de amicitia quod amicus Iesu Ioannes de caritate commemorat: Deus amicitia est?".

${ }^{13}$ Elred z Rievaulx 2010, I, 70: „Inusitatum quidem hoc, nec ex Scripturis habet auctoritatem. Quod tamen sequitur de caritate, amicitiae profecto dare non dubito, quoniam: qui manet in amicitia, in Deo Manet, et Deus in eo".
} 
wychowywana w dobie kryzysu ojcostwa, nie zawsze może zrozumieć i następnie przyjąć takie pojmowanie Boga, tym bardziej jeśli $\mathrm{w}$ danej rodzinie ziemski ojciec nie jest ideałem i nie może stać się właściwym paradygmatem dla relacji z Bogiem. W tak zarysowanym kontekście, przy zastosowaniu teologiczno-moralnego prawa stopniowości, przyjaźń może okazać się pomostem pomiędzy niewiarą a wiarą w Boga pojmowanego jako dobry Ojciec, a więc szansą na ewangelizację młodzieży, dla której przyjaźń pozostaje ważnym wyznacznikiem w życiu ${ }^{14}$.

Młody, należycie ukształtowany, człowiek może dostrzec, że przyjaźń z Bogiem jest również szansą na poprawne kształtowanie ziemskich przyjaźni. Elred z Rievaulx wskazuje bardzo jasno w swoim dziele, że gwarantem trwałości takiej więzi jest przyjaźń z Jezusem Chrystusem. Ustami Iwona stwierdza nawet jednoznacznie, że „prawdziwa przyjaźń nie może istnieć pomiędzy tymi, którzy żyją bez Chrystusa" (Elred z Rievaulx 2010, I, 16). Cel każdej takiej relacji, jej początek, kształtowanie, podtrzymywanie, winno być ukierunkowane na Niego (por. Rutecki 2017, s. 74). Idąc tym tropem, należy jeszcze dodać, że sama osoba przyjaciela może nawet stać się drogą młodego człowieka do odkrycia Boga i wiary w Niego. Altruistyczne wartości płynące z przyjaźni mogą otworzyć młodego człowieka na poszukiwanie prawdy oraz korzeni jego egzystencji, a także uspokoić jego uczucia i emocje. Ponadto dobroć płynąca od przyjaciela może przyczynić się do odkrywania dobroci Boga i refleksji nad tym, gdzie znajduje się źródło owej dobroci, a w końcu miłości ${ }^{15}$. Kevin O'Neil uważa nawet, że tylko wtedy, kiedy przyjaźń otwiera się na relację z Bogiem, może zaspokoić ludzkiego ducha i poprowadzić ludzkie serce do wypełnienia (por. O’Neil 1996, s. 109). Ewangelizacja młodzieży może więc znaleźć potężnego sprzymierzeńca w doświadczeniu przyjaźni. Na potwierdzenie tej tezy, warto przytoczyć zakończenie dzieła opata z Rievaulx, który jednoznacznie zauważył, że miłość do przyjaciela prowadzi wprost do miłości do Chrystusa i sięga samej wieczności:

W ten sposób, wznosząc się od owej świętej miłości, którą obejmujemy przyjaciela, dochodzimy do miłości, która jednoczy nas z Chrystusem, aby z radością w pełni kosztować owoców duchowej przyjaźni, oczekując na jej spełnienie

${ }^{14}$ Por. Graczyk 2017, s. 336: "Va sottolineato ancora che l'amicizia con Gesù Cristo può costituire un paradigma per edificare un giusto e fruttuoso rapporto con Dio. Questo modello può essere molto utile nell'opera dell'evangelizzazione, specialmente nella pastorale giovanile, perché spesso, per gli adolescenti, l'amicizia è l'unico punto di riferimento, quando i rapporti familiari sono in qualche modo problematici"; Schnackenburg 2007, s. 6-9.

${ }^{15}$ Por. Billy 2002, s. 77: "Friendship, for Aelred, is the medicine of life because it moves two people along this wide spectrum of relationships and enables them eventually to meet Christ face to face. It calms their disordered passions, enables their spirits to mingle, and eventually brings them to an intimate relationship with the Spirit of Christ". 
w przyszłości, kiedy minie strach, sprawiający, że teraz lękamy się i martwimy o siebie nawzajem, znikną wszelkie przeciwności, które teraz musimy pokonywać jeden dla drugiego, ponadto gdy wraz z samą śmiercią zniszczony zostanie jej oścień, którego ukłucia teraz często nam doskwierają i w konsekwencji sprawiają, że bolejemy jedni nad drugimi, kiedy zapanuje pełne bezpieczeństwo, ucieszymy się z tego, że to największe dobro będzie istnieć wiecznie. Stanie się to wtedy, kiedy przyjaźń, którą tutaj nieliczni tylko osiągają, rozciągnie się na wszystkich, a od wszystkich skieruje się ku Bogu, kiedy Bóg będzie wszystkim we wszystkich (Elred z Rievaulx 2010, III, 134).

\section{Przyjaźń duchowa jako remedium concupiscentiae?}

Elred z Rievaulx z pewnością był świadomy również wielu zagrożeń, które niesie ze sobą pragnienie budowania przyjaźni, szczególnie przez ludzi młodych. Nasz przewodnik po jej meandrach ukazuje, że przyjaźń w tej grupie wiekowej może bazować bardziej na uczuciach i emocjach niż na osądzie rozumu czy cnocie. Charakteryzuje taką więź jako bezmyślną, nieodpowiedzialną, nieumiarkowaną, bezwzględną, przewrotną i nietrwałą (por. Elred z Rievaulx 2010, II, 57-58). Taką młodzieńczą relację, która jest kierowana przez uczucia, Elred zdecydowanie odradza i nie nazywa jej nawet przyjaźnią, lecz trucizną, a ta prowadzi nawet do cielesnej pożądliwości (por. Elred z Rievaulx 2010, II, 58). Możliwe, że na podstawie własnych młodzieńczych przyjaźni nasz autor stwierdza, że przyjaźń źle pojmowana może prowadzić do zguby młodego człowieka, a nie do jego wzrostu. Świadomy tych zagrożeń, wskazuje, że to rozum winien kierować więzią z drugą osobą, a nie uczucia. Przyjaźń jest cnotą, a więc również wynikiem ludzkiego działania i ludzkiego osądu nie jest jedynie owocem pojawiających się uczuć (por. Elred z Rievaulx 2010, III, 118). Magdalena Czubak wskazuje:

Błędem byłoby więc analizowanie doktryny Aelreda przede wszystkim w aspekcie czysto uczuciowym czy też zmysłowym. W jego przekonaniu, przyjaźń wykracza bowiem poza obszar emocji. Nie można jej więc traktować jako zjawiska, które lokowałoby się wyłącznie w sferze uczuć. Należy też zauważyć, iż choć Aelred zastępuje cycerońskie słowo caritas pojęciem affectus, to drugi z wymienionych terminów rozumie on znacznie szerzej niż większość współczesnych mu myślicieli. Według niego skłonność jest w przyjaźni ściśle powiązana zarówno ze sferą woluntarystyczną, jak i z racjonalną; można nawet powiedzieć, że jest trwałą więzią serca, dobrej woli oraz rozumu (Czubak 2004, s. 73).

Sam Elred jasno wskazuje, że ,z rozumu i uczucia zarazem - kiedy ten, kogo rozum zaleca kochać z powodu jego cnoty, oddziałuje także na serce 
miłym zachowaniem i wdziękiem czystego życia; wówczas rozum łączy się z uczuciem w taki sposób, że dzięki rozumowi miłość ta jest czysta, a dzięki uczuciu - słodka" (Elred z Rievaulx 2010, III, 3). Pomimo zagrożeń, przyjaźń jest więc w stanie kształtować człowieczeństwo młodego człowieka, wychowywać go, tym bardziej w tak istotnych sferach jego życia jak miłość i relacje z drugim człowiekiem. Kevin O’Neil uznaje nawet, że przyjaźń jest niezbędna do osiągnięcia dojrzałości personalnej (por. O’Neil 1996, s. 98-99).

Dzięki przyjaźni młody człowiek może uczyć się właściwego przeżywania tego, kim jest. Poprzez relacje z drugim może on wyjść poza własne, egoistyczne potrzeby i pragnienia, poza swój własny, partykularny interes (por. Raguž 2013, s. 34). Dlatego uważam, że przyjaźń może odegrać znaczącą rolę w kształtowaniu właściwego przeżywania własnej seksualności oraz bycia mężczyzną czy bycia kobietą. Choć sam Elred rozróżnia przyjaźń od miłości oblubieńczej (por. Elred z Rievaulx 2010, II, 18-19), to dzięki doświadczeniu przyjaźni szlachetne pragnienia młodego człowieka, a więc tworzywo dla miłości agape, mogą połączyć się z wymiarem eros miłości pomiędzy mężczyzną a kobietą ${ }^{16}$. Nie każda przyjaźń między mężczyzną a kobietą przekształci się w miłość oblubieńczą i wcale nie musi się nią stać, ale z pewnością istnieje taka możliwość i dlatego przyjaźń między nimi może być fundamentem, na którym młodzi będą mogli budować swoją relację miłości. Możemy więc zaryzykować pewną hipotezę. Rzecz w tym, że skoro przyjaźń uczy właściwej miłości, jednoczy jej wymiar agapiczny z wymiarem erotycznym, to przyjaźń można uznać za formę „lekarstwa” na dzisiejszą rozerotyzowaną kulturę, promującą niczym nieograniczoną wolność seksualną w postaci wolnych związków, małżeństw na próbę, współżycia przedmałżeńskiego. Przyjaźń duchowa, zgodnie z myślą Elreda z Rievaulx, jawi się jako pewne remedium concupiscentiae na kulturę erotyki oraz płynne relacje powszechne w dzisiejszych społeczeństwach.

W kontekście całej Przyjaźni duchowej Elreda z Rievaulx widać jasno, że przyjaźń jest formą miłości i można śmiało mówić o istnieniu jej między przyjaciółmi. Dla młodych ludzi takie rozumienie przyjaźni może być pewnym zaskoczeniem, ale również szansą, co już wielokrotnie zostało wskazane w niniejszym opracowaniu. Sądzę, że dla młodzieży zawiązywanie więzów przyjaźni oraz trwanie w niej może stanowić „,szkołę” miłości chrześcijańskiej oraz miłości oblubieńczej (por. Czubak 2004, s. 74). Według Magdaleny Czubak (por. Czubak 2004, s. 80) ${ }^{17}$ Elred, nawiązując do biblijnego opisu stworzenia kobiety z mężczyzny, sugeruje, że równość dwóch płci implikuje możliwość

\footnotetext{
${ }^{16}$ Por. Baldini 1998, s. 14: "L'amicizia è, dunque, una via aperta verso la trascendenza, essa unisce la ragione al sentimento, l'agape con l'eros"; Baldini 2001, s. 44.

${ }^{17}$ Zob. także: Billy 2002, s. 70: "Aelred goes on with a beautiful description of the equality of the sexes and the need for friendship as the basis of their existence and mutual relationship".
} 
istnienia przyjaźni między mężczyzną a kobietą, która przecież może mieć charakter oblubieńczy, co prowadzi do zjednoczenia tych dwóch podmiotów:

W końcu, gdy Bóg stworzył człowieka, aby bardziej jeszcze uwypuklić dobro, jakim jest wspólnota, powiedział: Nie jest dobrze, aby człowiek byt sam; uczyńmy mu podobna do niego pomoc. I z pewnością Moc Boża nie uformowała tej pomocy z podobnej lub choćby z identycznej materii, aby ich bardziej pobudzić do miłości i przyjaźni, utworzyła kobietę z substancji mężczyzny. Pięknie zaś drugi byt ludzki wyprowadza $\mathrm{z}$ boku pierwszego człowieka, tak jakby natura uczyła nas, iż wszyscy są sobie równi, niczym pochodzący z jednego boku, i że w sprawach ludzkich nie ma wyższych lub niższych, co jest oznaką przyjaźni (Elred z Rievaulx 2010, I, 57).

Przyjaźń może więc odgrywać znaczącą rolę we właściwym kształtowaniu się relacji między mężczyzną a kobietą, tym bardziej, jeśli ma to być relacja dążąca w naturalny sposób do życia w małżeństwie. W tym wypadku przyjaźń stanowi element przygotowania do relacji sakramentalnej i intymnej, czyli jest swoistego rodzaju „katechumenatem” życia małżeńskiego dla ludzi młodych. Skoro przyjaźń duchowa zakłada obecność samego Chrystusa ${ }^{18}$, to tym bardziej może stanowić pomost między formą koleżeństwa, stanem zakochania a małżeństwem. Właśnie zorientowanie przyjaźni na Boga, na transcendencję, sprawia, że jest ona zarówno osobistą sprawą danych podmiotów, jak i więzią społeczną, budującą relacje, które stanowią fundament danego społeczeństwa, a więc relacje małżeńskie i rodzinne ${ }^{19}$. Właściwie przeżywana przyjaźń, również przyjaźń duchowa, rozumiana w duchu Mistrza z Rievaulx, wybawia młodych ludzi ze zbytniej koncentracji na samych sobie i swoich potrzebach, prowadzi ich od postaw egoistycznych do altruistycznych, od troski o siebie do troski o przyjaciela, a więc może stanowić właściwy paradygmat dla budowania każdej relacji, tym bardziej relacji oblubieńczej (por. O’Neil 1996, s. 103).

Takie spojrzenie na rolę odpowiednio rozumianej przyjaźni w procesie tworzenia się relacji oblubieńczej między mężczyzną a kobietą potwierdza Karol Wojtyła w swoim dziele Miłość i odpowiedzialność, gdzie wskazuje na wartość przyjaźni jako etapu w dorastaniu do miłości oblubieńczej. Karol Wojtyła wskazuje, że relacja mężczyzny i kobiety nie bazuje tylko na uczuciu i sympatii, ale również na przyjaźni, a więc dotyka woli człowieka. Sama sympatia nie wystarczy, aby budować trwałą relację, i dlatego musi się

${ }^{18}$ Por. Elred z Rievaulx 2010, I, 1: „Oto jesteśmy, ja i ty, i mam nadzieję, że jako trzeci jest pomiędzy nami Chrystus".

${ }^{19}$ Por. Raguž 2013, s. 40: "In ogni amicizia deve esserci il terzo, Gesù Cristo [...] Poiché è orientata fuori da se stessa, verso Gesù, la vera amicizia è sempre particolare e universale, individuale e sociale, «universale concretum». Le meditazioni di Aelredo possono aiutare anche i giovani non soltanto a stringere e vivere la vera amicizia, ma anche a trovare l'amico o l'amica nel matrimonio". 
ona stawać przyjaźnią (por. Wojtyła 2001, s. 82-84). Przyjaźń jest już decyzją woli, angażuje nie tylko uczucia człowieka, ale jego całego - pojawia się pragnienie dobra dla drugiej osoby, a więc benevolentia, postawa życzliwości: ,[...] przyjaźń bierze istotnie w posiadanie całego człowieka, jest ona jego dziełem, zawiera w sobie wyraźny wybór osoby, drugiego ja, do którego się zwraca, podczas gdy to wszystko w granicach sympatii jeszcze się nie dokonało"20. Dalej autor zauważa, że małżeństwo nie może być oparte na uczuciu, sympatii, ale właśnie na przyjaźni. Częstym błędem młodych ludzi jest budowanie swojego związku na samej sympatii i niekształtowanie z niej, w sposób świadomy i wolny, relacji przyjacielskiej. Miłość, innymi słowy, to ciągłe przekształcanie sympatii w przyjaźń (por. Wojtyła 2001, s. 85-86). Przyjaźń duchowa Elreda z Rievaulx może więc przyczynić się do „wychowania” relacji mężczyzny i kobiety oraz skierowania jej na właściwe tory, tym bardziej że dzięki niej młodzi ludzie będą uczyć się jakże istotnej cechy życia małżeńskiego, to jest wierności:

W przyjaźni nie ma nic ważniejszego nad wierność, która wydaje się być jej żywicielką i strażniczką. Ona to pozostaje niezmienna we wszystkich sytuacjach: w przeciwnościach i pomyślnościach, w radościach i smutkach, w sprawach przyjemnych i przykrych; tym samym okiem patrzy na małego i na wielkiego, biednego i bogatego, mocnego i słabego, zdrowego i chorego. Wierny przyjaciel nie widzi niczego, co jest poza sercem przyjaciela; lgnie ku cnocie, która jest na właściwym sobie miejscu, niewiele troszcząc się o wszystko inne, co istnieje jakby poza nim, i nie szukając, jeśli czegoś brak (por. Elred z Rievaulx 2010, III, 62).

\section{Przyjaźń drogą do pięknego życia}

Wizja przyjaźni duchowej Elreda z Rievaulx ma jeszcze jeden ważny atut, dzięki któremu może stanowić właściwe remedium na kryzys przyjaźni wśród ludzi młodych, a mianowicie ma walor wychowawczy i może być drogą do pięknego życia. Opat cysterski, o czym świadczy jego najważniejsze dzieło, miał niezwykłą zdolność optymistycznego spojrzenia na człowieka, żyjącego w przyjaźni (por. Rutecki 2017, s. 92-93). Było to spojrzenie pełne dobroci i wyrozumiałości, ale zarazem wymagające. Przyjaźń w jego ujęciu była sposobem wychowania człowieka i kształtowania relacji, w których żyje. Elred nie zakłada, że istnieją ludzie niezdolni do przyjaźni. Chociaż pewne cechy charakteru sprawiają, że budowanie takiej relacji będzie trudne (por. Elred

${ }^{20}$ Wojtyła 2001, s. 84. Przyjaźń będzie odgrywać również ogromną rolę w istniejącym już małżeństwie, dlatego można mówić o specyficznej przyjaźni małżeńskiej. Więcej na ten temat: Maritain, Maritain 1989. 
z Rievaulx 2010, III, 32). Zdaniem Mistrza z Rievaulx, istnieje możliwość uratowania każdej więzi między ludźmi, odpowiedniego zwrócenia uwagi na problemy w postaci przyjacielskiego upomnienia, ponieważ przyjaźń duchowa nie zakłada, że tworzą ją ludzie już ukształtowani, doskonali, ale będący w drodze do ewangelicznej doskonałości opartej na łasce Bożej (por. Pezzini 2004, s. 75-77). Bazując na doświadczeniu przyjaźni, można nawet przeinterpretować całe życie moralne i sprowadzić je na właściwe tory (por. Pezzini 2004, s. 79-80). Z założenia przyjaźń prowadzi zawsze ku dobru, ale prowadzi ludzi, którzy nie są doskonali pod względem moralnym, lecz pragną rzeczywiście wzrastać pod względem ludzkim, moralnym i duchowym, dlatego są w drodze, ale jeszcze nie na mecie, walczą ze swoimi wadami, a nie przyzwalają na nie, są dobrzy w możności, choć nie zawsze w akcie, wreszcie nie są gotowym produktem, ale chcą stawać się przyjaciółmi ${ }^{21}$.

Jakich więc wartości może nauczyć ludzi młodych przyjaźń? Zgodnie z koncepcją Elreda, uczy ona przede wszystkim trudnej sztuki komunikacji i mówienia prawdy, wolności od kłamstwa i pustego pochlebstwa. Prawa przyjaźni domagają się odpowiedniego języka, szczerości i upomnienia przyjaciela, jeżeli zachodzi taka potrzeba (por. Elred z Rievaulx 2010, III, 104-105; Billy 2002, s. 80). Przyjaźń uczy więc, że prawda przekazana z miłością i szacunkiem umacnia relacje ludzkie, a nie je osłabia. W ten sposób służy oczyszczeniu ludzkiego ego, w którym dzielę się z przyjacielem najcenniejszym darem - życiem:

Biada samotnemu, bo gdy upadnie, nie ma drugiego, który by go podniósł. Otóż prawdziwie samotnym jest ten, kto nie ma przyjaciela. Jakże wielkim natomiast szczęściem, spokojem i radością napawa posiadanie kogoś, z kim odważyłbyś się rozmawiać jak z samym sobą, komu nie obawiałbyś się wyznać swoich wykroczeń, przed kim nie wstydziłbyś się opowiedzieć o swoim rozwoju duchowym, komu powierzyłbyś wszystkie tajemnice i zamiary swojego serca. Czy istnieje coś milszego, niż tak mocne zjednoczenie dusz, i stworzenie jednego z dwojga, iż znika obawa przed próżnością i podejrzeniami; kiedy jeden na drugiego nie unosi się gniewem za skarcenie i wie, że pochwała nie ma nic wspólnego z pochlebstwem? (Elred z Rievaulx 2010, II, 11).

To zjednoczenie dusz, na które wskazuje Elred, dokonuje się stopniowo, ponieważ przyjaźń tworzy się między ludźmi w pewnych etapach: wybór, próba, dopuszczenie do przyjaźni, zgodność w sprawach ludzkich i boskich wraz

${ }^{21}$ Por. Elred z Rievaulx 2010, I, 35. 46; Billy 2002, s. 75: "It does not mean that a person is perfect or that he or she has never committed sin or will not do so in the future. A good person, for Aelred, is someone who intends not to sin and who takes appropriate measures to keep himself or herself from being overcome by unruly passions"; Grzywocz 2014, Konferencja 1. 
z życzliwością i miłością (por. Elred z Rievaulx 2010, III, 8). Relacja przyjaźni uczy młodego człowieka wysiłku i zakłada nieustanną pracę nad sobą w celu dorastania do tego wzniosłego ideału. Nie jest to łatwe szczególnie dzisiaj, kiedy młodzież jest przyzwyczajona do życia typu fast-food, a więc otrzymywania szybkich rezultatów swojej pracy.

Wszelkie niepowodzenia $\mathrm{w}$ dziedzinie relacji interpersonalnych prowadzą młodego człowieka do wielu życiowych kryzysów, zwłaszcza wtedy kiedy nie znajduje on oparcia w wartościach religijnych i duchowych. Przyjaźń duchowa może go natomiast nauczyć cierpliwego oczekiwania na owoce codziennej pracy nad sobą, a także sztuki wybaczania sobie oraz drugiemu człowiekowi, tym bardziej przyjacielowi (por. Elred z Rievaulx 2010, III, 17). Młody człowiek dostrzega wraz z upływem czasu słabość swojego przyjaciela, ale zauważa również własne braki, które wcale nie muszą oznaczać końca danej relacji. Mistrz z Rievaulx zachęca do cierpliwej miłości oraz znoszenia wad swojego przyjaciela, a w końcu do pracy nad sobą i nad drugą osobą: ,,[...] Lecz i u tych, którzy zostali poddani próbie i uznani za godnych, wy chodzą na wierzch wady szkodzące i samym przyjaciołom i ludziom obcym, ale niesława, jaką za sobą pociągają, spada jednak na przyjaciół. Wobec takich przyjaciół należy postępować z wielką troską i starać się ich uleczyć" (Elred z Rievaulx 2010, III, 40). Według naszego autora kryzys w przyjaźni jawi się jako szansa wzrastania, a nie impuls do zerwania relacji, a nawet gdy do niego dochodzi, to należy wciąż kochać taką osobę, ponieważ pewne ślady danej przyjaźni na zawsze pozostają w człowieku (por. Elred z Rievaulx 2010, III, 49-52). Choć przyjaźń zakłada równość i podobieństwo podmiotów ją tworzących, to jednak Mistrz z Rievaulx wskazuje, że nie oznacza to zgody we wszystkim (por. Czubak 2004, s. 71-72). Definiując ten rodzaj więzi, określa ją jako zgodność „w sprawach ludzkich i boskich, połączoną z życzliwością i miłością" (Elred z Rievaulx 2010, I, 11), ale nie wskazuje, że jest to całkowita zgodność, ponieważ taka relacja byłaby niemożliwa. Przyjaciel jest więc wezwany do akceptacji odmienności swojego przyjaciela oraz - pomimo podobieństwa i zgody $\mathrm{w}$ wielu kwestiach - szanowania jego osobistej wolności i poglądów.

Życie w przyjaźni z pewnością uczy poświęcenia, a granicą tej relacji jest oddawanie życia za przyjaciela: „Sam Chrystus ustalił wyraźną granicę przyjaźni, mówiąc: Nikt nie ma większej miłości od tej, niż gdy ktoś życie swoje oddaje za przyjaciół swoich. Oto jak daleko winna sięgać miłość pomiędzy przyjaciółmi: chcieć umrzeć za drugiego"22. Analiza dzieła cysterskiego autora wskazuje, że nie miał on na myśli jedynie śmierci w sensie fizycznym czy nawet męczeństwa, ale również codzienne poświęce-

${ }^{22}$ Elred z Rievaulx 2010, II, 33. Por. Billy 2002, s. 75-76. 
nie, tracenie siebie, czasu, energii, sił i zasobów materialnych dla przyjaciela. Przyjaźń nie wiąże się więc jedynie z przyjemnością i jakimś błogostanem, albowiem jest wymagająca, ale właśnie przez to piękna i pociągająca. Dla opata z Rievaulx jej praktykowanie jest w pewnym sensie ofiarą i naśladowaniem samego Chrystusa i bez Niego staje się niemożliwa. Poprzeczka duchowej przyjaźni jest więc postawiona bardzo wysoko, ale właśnie ta etyczna i duchowa wzniosłość przesłania dzieła Elreda może pociągnąć ludzi młodych do walki o piękno swojego życia i każdej relacji, którą tworzą.

\section{Przyjaźń obliczem milości}

Dla wielu ludzi młodych motywem szukania przyjaciół jest samotność, rodzinne konflikty, nieumiejętność poradzenia sobie z dorosłym życiem. Szukają zatem osób, z którymi mogliby dzielić swoje troski, ponieważ wewnętrznie przeczuwają, że przyjaźń będzie pomocą w ich sytuacjach granicznych, ale również we wspólnym radowaniu się z rzeczy dobrych. W wielu więc przypadkach ten rodzaj więzi jest okazją bardziej do realizacji samego siebie, a nie troski o rozwój przyjaciela czy samej przyjaźni. W dzisiejszą przyjaźń wkrada się jej największy wróg - egoizm. Szukanie przyjaciela jedynie dla zaspokojenia własnych potrzeb fizycznych czy psychicznych nie prowadzi jednak do poczucia spełnienia (por. Seidl 1995, s. 418-419). Konstruowane w hedonistyczny sposób relacje prędzej czy później przynoszą w końcu cierpienie i rozczarowanie. Lektura i analiza Przyjaźni duchowej Elreda z Rievaulx ukazuje, że celem takiej relacji pozostaje dobro, ale nie tylko moje osobiste, bo przede wszystkim liczy się szczęście przyjaciela, które daje satysfakcję również temu, kto obdarowuje. Przyjaźń duchowa jest niczym ciągła „,perychoreza”, w której tańczą ze sobą i przenikają się nawzajem eros, philia i agape, gdzie przyjaciel wiele daje, ale zarazem wiele otrzymuje od przyjaciela.

Podsumowując, możemy stwierdzić, że przyjaciel, aby nim był rzeczywiście, musi mieć konkretne oblicze i jest to oblicze miłości ${ }^{23}$. Młody człowiek bez doświadczenia przyjaźni nie będzie potrafił kochać konkretnie, a więc jego miłość będzie niestety abstrakcyjna. Natomiast przyjaźń, aby była prawdziwa, potrzebuje transcendentnego zakotwiczenia w Bogu, w którym odnajduje nie tylko swój fundament, ale również wzór etyczny. Przyjaźń duchowa Elreda z Rievaulx może prowadzić młodego człowieka do doświadczenia boskości, do właściwie rozumianej dywinizacji, którą jest trwanie w Bogu i z Bogiem

${ }^{23}$ Por. Coppi 2007, 149: “L'amico è e ha un volto, non è, dunque, un'astrazione, un universale, ma un particolare, una eccezione di cui conosco i caratteri peculiari come i suoi accidenti, di cui posso vedere il volto. Un amico, dunque, che è e ha il volto dell'amore". 
wraz z przyjacielem. Tak rozumiana więź może rzeczywiście uzdrawiać relacje, które jedynie ją imitują albo są jej karykaturami. Wizja duchowej przyjaźni Mistrza z Rievaulx nie jest oczywiście jedynym lekarstwem na współczesny kryzys tego typu relacji, ale może stanowić jedną z kilku alternatyw, które przyczynią się do właściwego postrzegania i przeżywania przyjaźni wśród ludzi młodych. Odpowiadając na pytanie zadane na początku, należy stwierdzić, że młodzi ludzie potrafią się zaprzyjaźnić, ale ich zadaniem jest nauczyć się przyjaźni. Propozycja przyjaźni duchowej Elreda z Rievaulx może stanowić istotną pomoc $\mathrm{w}$ realizacji tego zadania.

\author{
TO THE RESCUE OF THE TRUE CONCEPT OF FRIENDSHIP - \\ SPIRITUAL FRIENDSHIP BY AELRED OF RIEVAULX - A REMEDY \\ FOR THE CRISIS OF FRIENDSHIP AMONG YOUNG PEOPLE
}

\begin{abstract}
SUMMARY
The aim of the article is to give a proposal to the current crisis of the phenomenon of friendship, in particular friendship among young people. Out of many suggestions we can indicate the one that seems to be very up-to-date, that is, the proposal of the spiritual friendship of Aelred of Rievaulx. In his most famous work De spirituali amicitia, he criticizes relationships based only on usefulness, on pleasure and proposes a friendship founded on the love of Christ. According to the Cistercian abbot, friendship with Christ can be a paradigm for human close relationships, but also friendship with people can lead us to close bond with God. For young people, who are children of his time, it is very difficult to build relationships based on true love, therefore, Aelred's proposal could be a remedy to their problems in interpersonal relationships, indeed, true friendship, based on agapic love, lived in faith, can be a kind of therapy for the young people. Moreover, spiritual friendship could be a mean in the evangelization of the young. Finally, young people, who want to find a lifelong partner and create a family due to having friends, they can learn how to live in deep relationships. Thus, the theology of friendship of Aelred of Rievaulx constitutes a school of virtues for young people.
\end{abstract}

Keywords: friendship; Aelred of Rievaulx; young people; relationships; spiritual friendship; crisis of friendship; spousal love; evangelization

Słowa kluczowe: przyjaźń; Elred z Rievaulx; młodzież; relacje; przyjaźń duchowa; kryzys przyjaźni; miłość oblubieńcza; ewangelizacja 


\section{BIBLIOGRAFIA}

Aelredus Rievallensis, De Spirituali Amicitia, Migne PL 195, s. 659-702.

Alberoni F. (2006 $)$, L'amicizia, Milano.

Baldini M. (1998), L'amicizia secondo i filosofi, Roma.

Baldini M. (2001), La storia dell'amicizia, Roma.

Billy D.J. (2002), The Healing Role of Friendship in Aelred of Rievaulx's De Spiritali Amicitia, "Studia Moralia" 40, s. 63-84.

Capodieci S. (2012), Giuseppe. Storia di fratellanza e amicizia, Città del Vaticano.

Cicerone M.T. (1985), Laelius de amicitia, thum. C. Saggio, Milano.

Coppi P. (2007), Il volto dell'amicizia in Aelredo di Rievaulx, w: $\varphi 1 \lambda i ́ \alpha$. Riflessioni sull'amicizia. Atti di Convegno La necessità dell'amicizia presso la Pontificia Università della Santa Croce, red. M. D'Avenia, A. Acerbi, Roma, s. 149-156.

Czubak M. (2004), Teoria przyjaźni Aelreda z Rievaulx, „Etyka”, nr 37, s. 69-84.

Dotto G. (1995), «Caritas» ed amicizia nella spiritualità del secolo XII: Bernardo di Chiaravalle e Aelredo di Rievaulx, w: Il concetto di amicizia nella storia della cultura europea. Atti del XXII Convegno internazionale di studi italo-tedeschi, Merano, s. 546-557.

Elred z Rievaulx (2010), Przyjaźń duchowa, tłum. M. Wylęgała, Kielce.

Graczyk W. (2017), Implicazioni morali della teologia dell'amicizia nel Vangelo di Giovanni. Dissertatio ad Doctoratum in Theologia Morali consequendum, Calisia.

Grzywocz K. (2014), W duchu i przyjaźni, Audiobook, Kraków.

Majkrzak H. (2006), Mitość i przyjaźń, Kraków.

Maritain J., Maritain R. (1989), Matrimonio, amore e amicizia, red. G. Galeazzi, Milano.

Mendonça J.T. (2013), Nessun cammino sarà lungo. Per una teologia dell'amicizia, Milano.

Lodovici G.S. (2009), Il ritorno delle virtù. Temi salienti della "Virtue Ethics", Milano.

O'Neil K. (1996), Forming Right Relationships, w: Spirituality and Morality, red. D.J. Billy, D.L. Orsuto, New York, s. 97-111.

Pezzini D. (2004), Introduzione, w: Aelredo di Rievaulx, L'amicizia spirituale, Milano, s. 7-80.

Raguž I. (2013), „Ecce ego et tu, et spero quod tertius inter nos Christus sit”. Aelredo di Rievaulx sull'amicizia, "Communio" 237, s. 32-41.

Rutecki M. (2017), Przyjaciel, moja drogą do Boga, Kraków.

Schnackenburg R. (2007), Amicizia con Gesù, Brescia.

Seidl H. (1995), Condizioni dell'amicizia oggi, w: Il concetto di amicizia nella storia della cultura europea. Atti del XXII Convegno internazionale di studi italo-tedeschi, Merano, s. 405-421.

Wojtyła K. (2001), Miłość i odpowiedzialność, Lublin.

Wylęgała M. (2010), Wstęp, w: Elred z Rievaulx, Przyjaźń duchowa, thum. M. Wylęgała, Kielce, s. $12-18$.

WALDEMAR GraczyK (ur. 1984), kapłan diecezji kaliskiej (2009), doktor teologii moralnej, absolwent Accademia Alfonsiana w Rzymie (2017), prefekt i wykładowca Wyższego Seminarium Duchownego Diecezji Kaliskiej, kierownik Internatu Zespołu Szkół Technicznych Diecezji Kaliskiej w Kaliszu, wicekanclerz Kurii Diecezjalnej w Kaliszu 